\title{
APLIKASI PENGENALAN PAHLAWAN NASIONAL DAN PAHLAWAN REVOLUSI BERBASIS ANDROID
}

\author{
Jodi Hendrawan ${ }^{1}$, Ika Devi Perwitasari ${ }^{2}$ \\ ${ }^{1,2}$ Universitas Pembangunan Panca Budi Medan \\ Jln. Gatot Subroto km. 4.5 Kec. Medan Sunggal Kota Medan, 20122 Indonesia
}

1 Jodihendrawan@dosen.pancabudi.ac.id, ${ }^{2}$ Ikadeviperwiatsariedosen.pancabudi.ac.id

\begin{abstract}
Heroes of revolution are titles or titles given to military officers who died in the betrayal tragedy of the G30S / PKI Indonesian Communist Party (PKI) which took place in Jakarta and Yogyakarta on September 30, 1965. National heroes are titles given to Indonesian citizens who fighting against occupation that had fallen in the battlefield. So that during his lifetime he left behind achievements or progress for the Republic of Indonesia. Where currently there is minimal knowledge of students or students regarding hero figures and lack of media for the introduction of heroes in Indonesia. With this, the application of national hero recognition and android-based revolution heroes is designed. So that it can increase the knowledge and interests of students or students and increase their sense of nationalism. System development is carried out with the watefall model and uses the concept of object-oriented development, OOP (Object Oriented Programming) and uses the UML modeling process (Unified Modeling Language) for the development of national recognition applications and android-based revolution heroes.
\end{abstract}

Keywords - Android, Applications, UML, OOP, Heroes.

Abstrak - Pahlawan revolusi merupakan gelar atau sebutan yang diberikan kepada perwira militer yang gugur dalam tragedi pengkhianatan Partai Komunis Indonesia (PKI) G30S/PKI yang terjadi di Jakarta dan Yogyakarta pada tanggal 30 September 1965. Pahlawan nasional adalah gelar yang diberikan kepada warga negara Indonesia yang berjuang melawan penjajahan yang telah gugur dimedan peperangan. Sehingga semasa hidupnya meninggalkan prestasi atau kemajuan untuk Negara Republik Indonesia. Dimana saat ini minim sekali pengetahuan siswa/i atau pelajar mengenai tokoh-tokoh pahlawan serta kurangnya media untuk pengenalan para pahlawan di Indonesia. Dengan adanya hal ini maka dilakukan perancangan aplikasi pengenalan pahlawan nasional dan pahlawan revolusi berbasis android. Sehingga dapat meningkatkan pengetahuan dan minat siswa/i atau pelajar serta menigkatkan rasa nasionalisme. Pengembangan sistem dilakukan dengan model watefall dan menggunakan konsep pengembangan berorientasi objek, OOP (Object Oriented Programming) serta menggunakan proses pemodelan UML (Unified Modeling Language) untuk pengembangan aplikasi pengenalan pahlawannasional dan pahlawan revolusi berbasis android.

Keywords - Android,Aplikasi, UML, OOP, Pahlawan.

\section{PENDAHULUAN}

\section{A. Latar Belakang}

Pahlawan adalah orang yang berjasa dan memberikan kontribusi bagi suatu individu, kelompok, baik itu suatu lembaga atau suatu negara. Adapun media pengenalan yang sangat umum untuk pengenalan terhadap tokoh-tokoh sejarah saat ini hanya berupa poster dan lembaran kertas serta kurangnya minat dan pengetahuan para pelajar akan pengetahuan tentang sejarah dan tokoh-tokoh ynag pernah berjasa yaitu pahlawan revolusi dan pahlawan nasional.

Pahlawan nasional adalah gelar yang diberikan kepada warga negara Indonesia yang berjuang melawan penjajahan yang telah gugur dimedan peperangan. Sehingga semasa hidupnya meninggalkan prestasi atau kemajuan untuk Negara Republik Indonesia. Dengan hal tersebut jasa-jasanya dikenang sebagi pahlawan nasional karena telah memberikan kontribusi yang sangat berarti untuk kemerdekaan Negara Kesatuan Republik Indonesia.Pahlawan Revolusi merupakan gelar atau sebutan yang diberikan kepada perwira militer yang gugur dalam tragedi pengkhianatan Partai Komunis
Indonesia (PKI) G30S/PKI yang terjadi di Jakarta dan Yogyakarta pada tanggal 30 September 1965. Dengan pemberian gelar tersebut bertujuan untuk dijadikan kenangan atas jasa-jasa dan perjuangan sehingga bangsa dan negara Indonesia bisa lebih maju seperti saat ini.

Saat ini dalam dunia pendidikan minim sekali pengenalan dan pembelajaran kan pengenalan tokohtokoh yang berjuang demi kemerdekaan Negara Kesatuan Republik Indonesia, yang seharusnya dikenalkan kepada genarasi penerus bangsa Indonesia sejak sudah mulai mengenyam bangku pendidikan.

Oleh karena itu, dengan adanya permasalahan dalam pengenalan tokoh-tokoh sejarah atau pahlawan dibutuhkan media pembelajaran atau pengenalan yang efektif melalui aplikasi berbasis android. Dimana android saat ini sudah dinikamti oleh semua kalangan sehingga memudahkan dalam proses pembelajaran atau pengenalan mengenai pengetahuan menjadi lebih efekti dan lebih efesien serta menigkatkan minat belajar khususnya siswa/i yang masih dibangku pendidikan. 


\section{LANDASAN TEORI}

\section{A. Mobile Application}

Mobile Application adalah sebuah aplikasi yang memungkinkan manusia melakukan mobilitas dengan menggunakan perlengkapan seperti PDA, telepon seluler (handphone). Dengan menggunakan aplikasi mobile, manusia dapat dengan mudah melakukan berbagai macam aktifitas mulai dari hiburan, berjualan, belajar, mengerjakan pekerjaan kantor, browsing, chatting, email, dan lain sebagainya. (Yonarisa, 2012) M-learning merupakan penyampaian bahan pembelajaran elektronik pada alat komputasi mobile agar dapat diakses dari mana saja dan kapan saja (Ally, 2004).

B. Sistem Operasi Android

Android adalah system operasi berbasi Linux yang di gunakan untuk telepon seluler (mobile) seperti telepon pintar (smartphone) dan komputer tablet (Yosef Murya, 2014:3).

Nazruddin Safaat dalam bukunya Android Pemrograman Aplikasi Mobile Smartphone dan Tablet PC Berbasis Android revisi kedua (2014:1-2) mendefinisikan Android adalah sebuah sistem operasi untuk perangkat mobile berbasis linux yang mencakup sitem operasi, middleware dan aplikasi.

C. UML

UML (Unified Modelling Language) merupakan bahasa visual untuk pemodelan dan komunikasi mengenai sebuah sistem dengan menggunakan diagram dan teks-teks pendukung (Rosa dkk, 2013:137).

\section{METODOLOGI PENELITIAN}

\section{A. Kerangka Kerja Penelitian}

Disini diuraikan metodologi dan kerangka kerja penelitian digunakan untuk mengambarkan langkahlangkah yang akan diterapkan dalam melakukan penelitian.

Gambar. 1 di bawah ini merupakan kerangka kerja (framework) yang digunakan dalam penelitian ini:

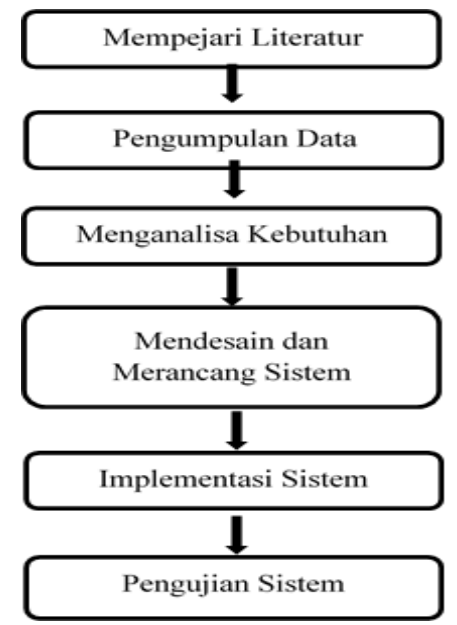

Gambar 3.1 Kerangka Kerja Penelitian
Berdasarkan gambar 3.1 penulis dapat menjelaskan beberapa kerangka kerja yang akan dilakukan dalam penelitian ini, yaitu sebagai berikut :

\section{Mempelajari Literatur}

Pada penelitian ini dipelajari literatur yang berhubungan dengan permasalahan. Kemudian literatur yang dipelajari diseleksi untuk dapat ditentukan literatur mana yang akan digunakan dalam penelitian. Sumber literatur didapatkan dari perpustakaan, jurnal, artikel dan konsep-konsep lain yang mendukung dalam menyelesaikan sistem yang akan dibangun termasuk referensi.

2. Pengumpulan Data

Dalam melakukan penelitian ini, pengumpulan data dan informasi pada tahap ini dilakukan untuk mengetahui mengenai sistem yang diteliti. Dari data dan informasi yang dikumpulkan akan didapat data untuk pendukung penelitian serta pengumpulan data dilakukan untuk mengetahui kebutuhan dari pengguna. Metode yang digunakan penulis untuk pengumpulan data adalah sebagai berikut :

a. Observasi Observasi berguna untuk melakukan pengumpulan data dan observasi dengan langsung terjun kelapangan pada pihak-pihak yang terkait dalam menyelesaikan penelitian ini dimana informasi dan materi akan diperoleh sebagai bahan dari rancang bangun sistem.

b. Wawancara

Melakukan wawancara pada pihak yang berkaitan dengan alur permasalahan. Wawancara ini dilakukan untuk mendapatkan bahan penulisan dan penjelasan pengamatan yang dilakukan.

3. Analisa Kebutuhan

Analisis dapat didefinisikan sebagai penguraian dari suatu sistem informasi yang utuh kedalam bagian-bagian komponennya. Analisa kebutuhan ini bertujuan untuk mengetahui apa saja yang dibutuhkan dalam perancangan sistem yang di bangun dan mengetahui kebutuhan-kebutuhan pendukung dari perancangan sistem.

4. Desain dan Perancangan Sistem

Kegiatan desain sistem dilakukan untuk sebagai awal dari perancangan sistem yang akan dibangun sesuai kebutuhan. Pada tahap ini akan dilakukan pemodelan terhadap sistem yang akan dibangun dengan pemodelan UML (Unified Modelling Language). Dan pada tahap ini dilakukan perancangan antar muka terhadap sistem yang akan dibuat.
5. Implementasi Sistem
Implementasi sistem dilakukan sesuai desain dan rancangan antar muka aplikasi yang akan dibangun. Pada tahap ini melakukan pengkodingan atau pembuatan program sehingga sistem yang dirancang dapat digunakan oleh pengguna. 


\section{HASIL DAN PEMBAHASAN}

\section{A. Analisa Kebutuhan Fungsional}

Analisa sistem merupakan penguraian dari suatu sistem informasi kedalam komponen - komponennya dengan maksud mengindentifikasikan dan mengevaluasi permasalahan sehingga dapat diusulkan perbaikan - perbaikannya. Kebutuhan fungsional (fungsional requirement) adalah jenis kebutuhan yang berisi proses - proses apa saja yang akan dilakukan oleh system.

1. Aplikasi ini nantinya akan dapat menampilkan sebuah halaman awal dengan beberapa menu yaitu : menu pahlawan revolusi, menu pahlawan nasional, menu latihan, menu bantuan, menu tentang dan menu keluar.

2. Pada saat user mengklik salah satu menu, aplikasi akan menampilkan sebuah halaman baru yang berisi list atau daftar sub menu.

3. Ketika salah satu list atau daftar materi diklik, aplikasi akan menampilkan halaman yang berisi penjelasan tentang judul listview tersebut.

4. Aplikasi dapat menampilkan informasi mengenai pahlawan-pahlawan di Indonesia

5. Aplikasi dapat menampilkan soal-soal yang akan di kerjakan oleh user untuk menguji penguasaan materi yang ada. Soal akan di tampilkan saat user memilih menu latihan pada halaman awal.

6. Pada menu Bantuan, aplikasi akan menampilkan sebuah informasi bagaimana cara penggunaan aplikasi tersebut.

7. Pada menu Tentang, aplikasi akan menampilkan sebuah kotak dialog yang berisi informasi tentang aplikasi dan sebuah tombol konfirmasi.

8. Pada menu Keluar, aplikasi akan menampilkan kotak dialog konfirmasi dan dua buah tombol untuk konfirmasi.

B. Analisa kebutuhan non fungsional

Kebutuhan nonfungsional (nonfunctional requirements) adalah tipe kebutuhan yang berisi properti prilaku yang dimiliki oleh sistem, meliputi kebutuhan perangkat keras (hardware), kebutuhan perangkat lunak (software), dan kebutuhan sumber daya manusia (brainware)

1. Analisa kebutuhan perangkat keras (hardware)

Analisis kebutuhan perangkat keras bertujuan untuk mengetahui secara tepat perangkat keras yang dibutuhkan. Adapun hardware yang dibutuhkan untuk pembuatan dan penerapan aplikasi yaitu :

a. Laptop atau PC

b. Handphone : Samsung

2. Analisa kebutuhan perangkat lunak (software)

Perangkat lunak merupakan perangkat yang berfungsi untuk melakukan pengerjaan dalam data processing sistem untuk mendukung bekerjanya sistem-sistem komputer. Kebutuhan yang dibutuhkan adalah Sistem Operasi, serta kebutuhan-kebutuhan lainnya bisa didapatkan secara gratis karena aplikasi pendukung bersifat open source. Adapun software yang dibutuhkan untuk pembuatan dan penerapan aplikasi yaitu :

1. Kebutuhan software untuk pembuatan

a. SO Microsoft Windows XP, Windows 7

b. IDE Eclipse

c. Android SDK

d. ADT (Android Development Tools)

2. Kebutuhan software untuk penerapan

a. Sistem Operasi Android Jelly Bean 4.2

b. Start UML

c. Bahasa Pemrograman Java Android

C. Perancangan Aplikasi

Dalam pengembangan aplikasi yang berkualitas diperlukan aplat bantu perancangan dan sistem peracangan sesuai dengan sistem perangkat lunak. Adapun dalam proses peracangan perangkat lunak atau aplikasi menggunakan alat bantu UML (Unified Modeling Language) yang dapat menggambarkan bagaimana interface dan fungsi secara umum aplikasi yang akan dibangun.

1. Use Case Diagram

Use Case Diagram menggambarkan aktifitasaktifitas yang dapat dilakukan user terhadap aplikasi yang akan dibangun. Berikut adalah gambar dari use case diagram aplikasi pengenalan tokoh pahlawan nasional dan pahlawan revolusi berbasis android.

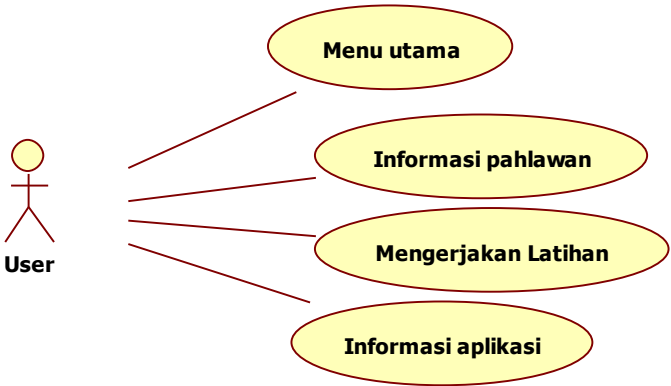

Gambar. 2 Use Case Diagram Aplikasi

\section{Activity Diagram}

Activity diagram menggambarkan aktifitasaktifitas yang dapat dilakukan oleh user didalam aplikasi ini. Pada gambar Activity Diagram di bawah ini dapat kita lihat aktifitas dari user yaitu user dapat mengakses berbagai konten seperti melihat materi, gambar, dan melihat informasi tentang aplikasi.

Aktivitas yang terdapat pada menu utama, yaitu user memulai menjalankan aplikasi, kemudian system akan menampilkan menu utama. Setelah menu utama muncul, maka user akan memilih salah satu bagian dari menu. Apabila user memilih menu keluar, maka aktifitas selesai. 


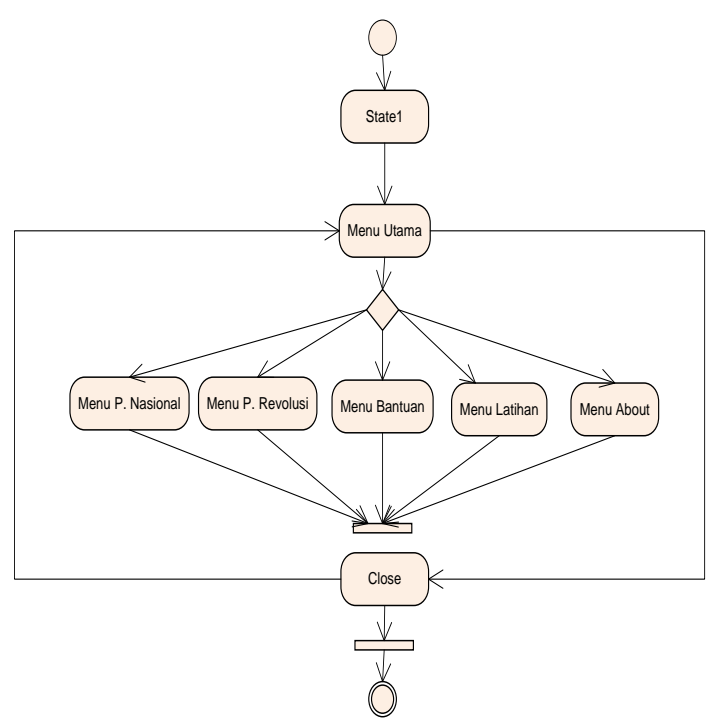

Gambar. 3 Actifity Diagram Aplikasi

\section{Class Diagram}

Class diagram menggambarkan kumpulan kelaskelas objek. Pada Class diagram ini akan dijelaskan tentang kelas-kelas yang terdapat pada aplikasi yang dibangun. Sebagaimana yang terlihat pada gambar Class diagram berikut, ada beberapa kelas yaitu splash screen, menu utama, pilihan menu pahlawan, pilihan latihan, tentang dan keluar.

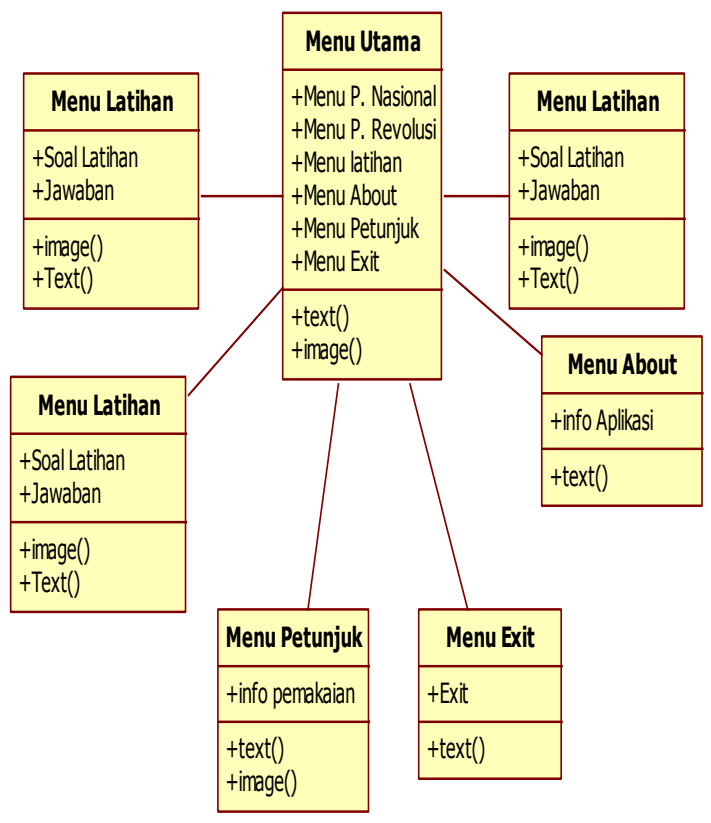

Gambar. 4 Class Diagram Aplikasi

D. Hasil pengujian Sistem

Pengujian aplikasi dilakukan agar aplikasi dapat dioperasikan oleh pengguna atau user dan mengetahui bagaimana bentuk tampilan aplikasi pada perangkat mobile pengguna.
1. Tampilan Antarmuka Icon Launcher Aplikasi

Untuk dapat mengakses aplikasi yang telah dirancang, pengguna dapat membuka melalui perangkat mobile dengan memilih icon launcher Aplikasi yang sudah terinstal pada perangkat mobile pengguna. Pada gambar. 5 dapat dilihat tampilan icon launcher Aplikasi sebagai berikut :

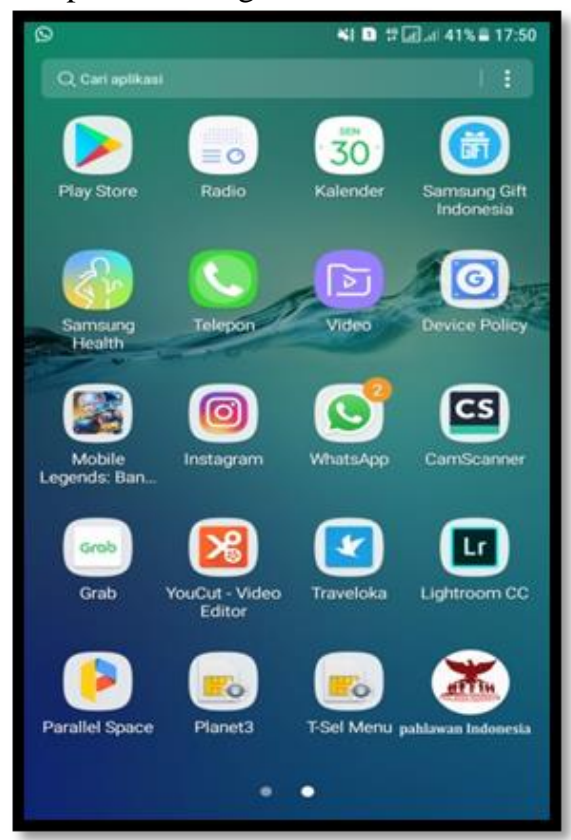

Gambar. 5 Tampilan Icon Launcher Aplikasi

2. Tampilan Antarmuka Splash Screen Aplikasi

Tampilan splash screen merupakan tampilan awal aplikasi ketika dijalankan pada perangkat mobile sebelum aplikasi menuju ke menu utama aplikasi. Halaman splash screen muncul saat pertama kali user membuka aplikasi pada device Android. Tampilan splash screen Aplikasi dapat dilihat pada gambar.6 berikut :

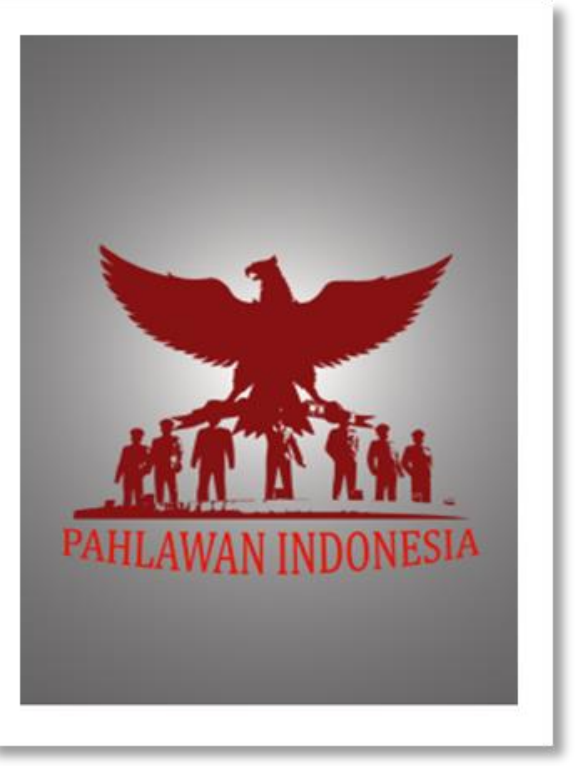

Gambar. 6 Tampilan Splash Screen Aplikasi 


\section{Tampilan Antarmuka Menu Utama}

Tampilan menu utama aplikasi akan menyajikan konten-konten dari informasi yang akan ditampilkan pada aplikasi yang ada diakses oleh user. Pada gambar. 7 dapat dilihat tampilan menu utama aplikasi yang menyajikan pilihan menu-menu layanan aplikasi sebagai berikut :

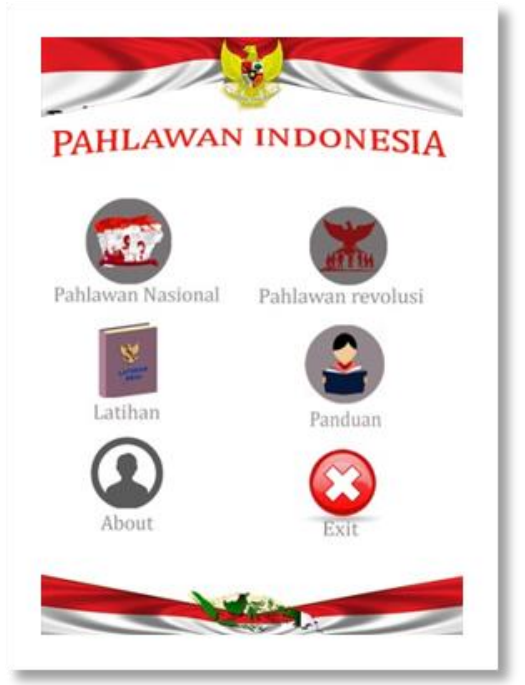

Gambar. 7 Tampilan Antarmuka Menu Utama

4. Tampilan Antarmuka Listview Menu Pahlawan

Ketika user memilih menu pahlawan maka akan tampil tampilan listview/isi dari menu yangdipilih. Pada gambar. 8 dapat dilihat tampilan antarmuka listview yang dapat dipilih oleh user pada menu pahlawan sebagai berikut :

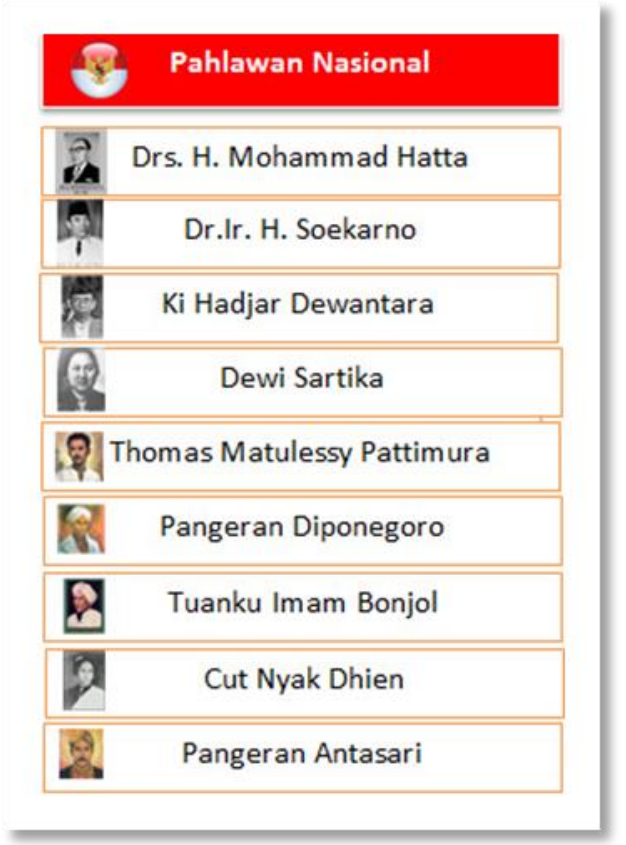

Gambar. 8 Tampilan Antarmuka Listview Menu Pahlawan

Pada gambar. 9 berikut dapat dilihat isi tampilan antarmuka salah satu listview dari menu pahlawan ditampilkan pada Aplikasi.

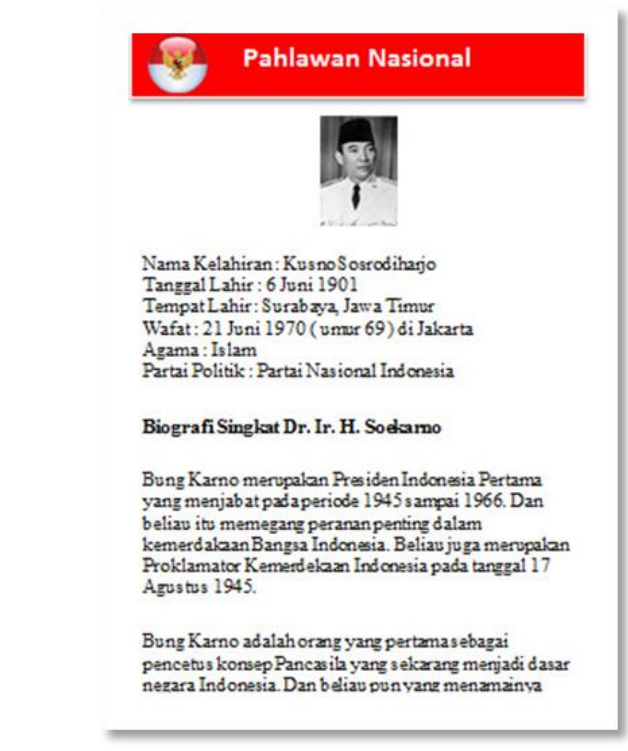

Gambar. 9 Tampilan Antarmuka Isi Listview nama pahlawan

5. Tampilan Antarmuka Listview Menu Latihan

Listview pada menu ini menampilkan soal-soal latihan terhadap pemahaman tentang infomasi yang ditampilkan dalam aplikasi. Dengan adanya uji pemahaman ini dapat mengukur tingkat pemahaman user mengenai informasi dari Aplikasi mengenai pahlawan di Indonesia. Pada gambar. 10 dapat dilihat tampilan soal-soal untuk latihan pada aplikasi.

\begin{tabular}{|cc|}
\hline & Soal-Soal Latihan \\
\hline & Soal 1 \\
\hline & Soal 2 \\
\hline & Soal 5 \\
\hline & Soal 6 \\
\hline & Soal 7 \\
\hline
\end{tabular}

Gambar. 10 Tampilan Antarmuka Listview Latihan

Pada gambar. 11 dapat dilihat tampilan soal latihan pada aplikasi. 


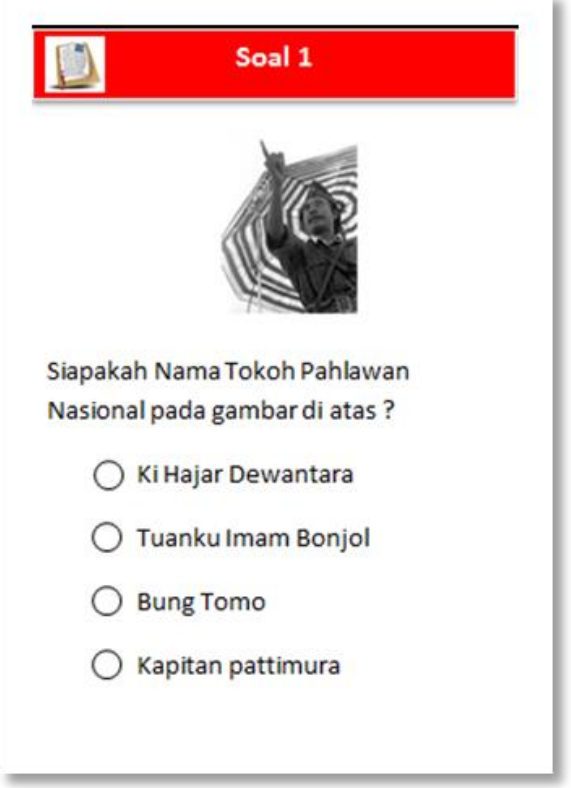

Gambar. 11 Tampilan Soal Latihan

\section{Rancangan Antarmuka About}

Menu tentang atau about berfungsi untuk menampilkan informasi tentang aplikasi ini. Informasi yang ditampilkan meliputi definisi fungsi dari aplikasi dan nama perancang aplikasi. Pada gambar. 12 dapat dilihat antarmuka tampilan informasi aplikasi dari menu about pada Aplikasi.

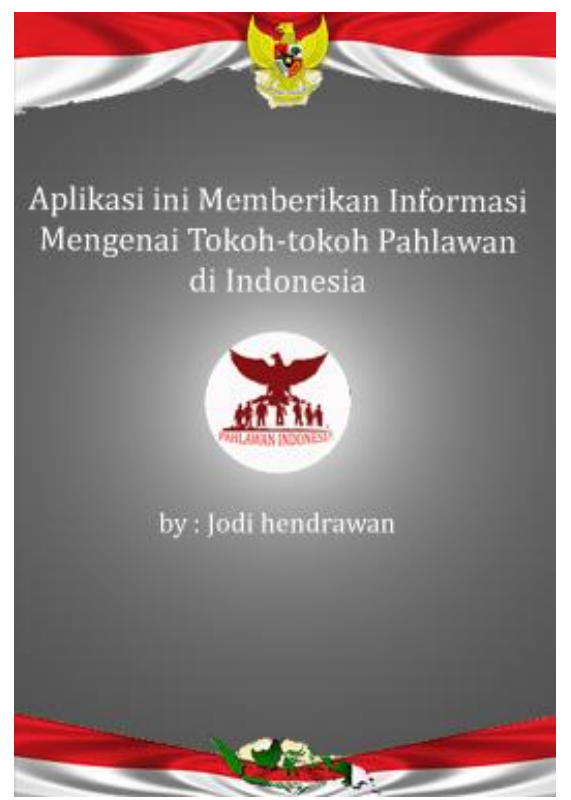

Gambar. 12 Tampilan Antarmuka About

\section{Rancangan Antarmuka Exit}

Menampilkan dialog konfirmasi kepada user jika ingin keluar dari aplikasi. Pada gambar. 13 dapat dilihat antarmuka tampilankonfirmasi kepada user ketika memilih menu exit.

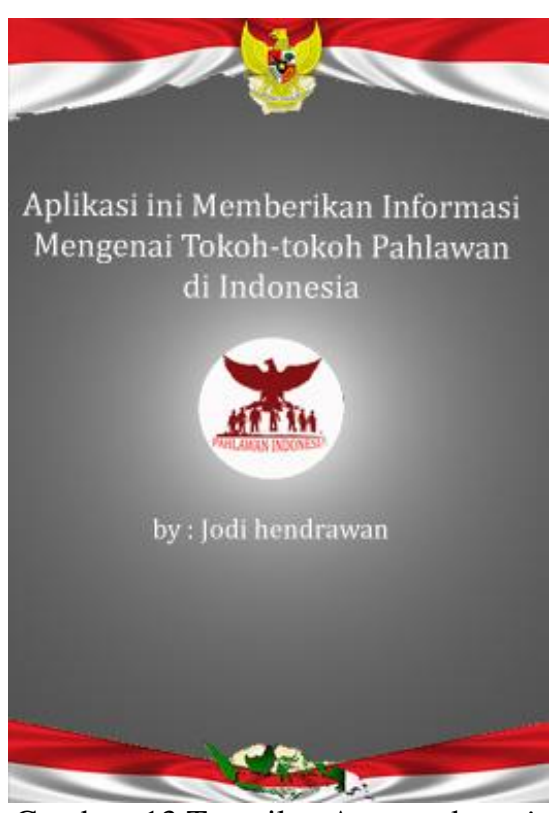

Gambar. 13 Tampilan Antarmuka exit

\section{PENUTUP}

\section{A. Kesimpulan}

Berdasarkan hasil dari rancang bangun Aplikasi Pengenalan Tokoh Pahlawan Nasional dan Pahlawan Revolusi dapat disimpulkan bahwa :

1. Dengan adanya aplikasi mobile learning yang dioperasikan pada perangkat mobile Android dapat memudahkan proses belajar tokoh pahlawan nasional dan pahlawan revolusi yang dapat dilakukan kapan saja dan di mana saja yang lebih interaktif dan efektif.

2. Penerapan metode sistem beorientasi objek pemodelan UML (Unified Modeling Language) dapat memberikan suatu pemodelan yang sangat kompleks dengan memberikan penggambaran alur sistem dan logika algoritma pada sistem yang dirancang.

\section{B. Saran}

Berdasarkan hasil penelitian, penulis menyadari masih banyak kekurangan dan dapat disempurnakan oleh pengembangang berikutnya. Untuk menyempurnakan penelitian ini penulis memberikan beberapa saran di antaranya :

1. Penyedian informasi pada aplikasi masih sangat terbatas, sehingga kedepannya dapat dikembangkan lagi dan mencangkup pembahasan lebih luas.

2. Aplikasi mobile learning ini dapat dikembangkan lebih lanjut dengan tampilan yang lebih interaktif dan lebih menarik.

3. Untuk keperluan tertentu aplikasi ini dapat dikembangkan dengan akses konten secara online sehingga konten yang ada bisa menyesuaikan dengan perkembangan sistem informasi dan teknologi. 


\section{REFERENSI}

[1] Ally, M. 2004. "Using learning theories to design instruction for mobile learning devices". Procedings of the Mobile Learning 2004 International Conference, Rome.

[2] Fatimah S.N , Artina N., 2016, Rancang Bangun Edukasi "Ceria” Berbasis Android Sebagai Media Pembelajaran Untuk Anak Usia Dini. STMIK MDP.

[3] Georgieva, dkk. Internasional converence on Computer Systems and technologies, 2004.

[4] Mulyadi. 2010. Membuat Aplikasi Untuk Android. Yogyakarta: Multimedia Center Publishing.

[5] Murya, Yosef. 2014, Pemrograman Android Blackbox. Jasakom

[6] Pressman, R,D.2010. Software Engineering : a Practitoner's Approach. McGraw-Hill, Network.

[7] Rosa dan M Shalahuddin. 2013. Rekayasa Perangkat Lunak: Terstruktur dan Berorientasi Objek. Bandung: Informatika.

[8] Safaat, Nazruddin. 2014. Pemrograman Aplikasi Mobile Smartphone dan Tablet PC Berbasis Android. Bandung: Informatika Bandung.

[9] Yonarisa, F. (2012, September 7). Mobile Apps. Retrieved Desember 18, 2013, from Kampusku Kampus IT: http://blog.akakom.ac.id/faridayonarisa/ 2012/09/07/mobile-apps/ 